\title{
Analysis of the Shortcomings of Financial Engineering in Traditional Risk Management Methods
}

\author{
Yuqi Xue ${ }^{1, *}$ \\ ${ }^{1}$ Shanghai Rongyue Private Entry-Exit Services Co., Ltd, Shanghai 200052, China \\ "Corresponding author. Email: sost12822@163.com
}

\begin{abstract}
With the progress of science and technology, in order to ensure the risk management, financial engineering has emerged. Among them, the effectiveness of risk management activities is directly related to the stability of cash flow. Financial engineering broadens people's thinking and reduces the cost of investment risk. The most important thing is to prevent social and economic friction to improve financial efficiency. This article will briefly compare financial engineering and traditional risk management in the three aspects of insurance, asset \& liability management and portfolio investment to analyze the comparative advantages of financial engineering.
\end{abstract}

\section{Keywords: financial engineering, risk management, comparative advantages}

\section{INTRODUCTION}

Expected loss refers to the amount of loss that can be expected during the normal operation of commercial banks. It is an indicator of credit risk. Banks usually set up loan loss reserves to buffer this part of the loss. Obviously, when the probability of default is established, the established default loss rate LGD (Loss given default represents the established default loss rate, reflecting the severity of the loss to the creditor once the debtor defaults). It is the amount of loss after the default and the total risk position before the default. The higher the exposure ratio is, the greater the credit risk and therefore the greater the expected loss will be. And in the operation of financial institutions, the expected loss could be financial risk. The management of financial risk is based on the identification of the risk and the control preparation for the possible risk, so as to reduce the risk. In the financial risk management, financial engineering is a new management method by using the tools of exchange price, futures, share option and so on. New financial instruments are derived from different types of financial products, so as to effectively avoid financial risks.

\section{SHORTCOMINGS OF TRADITIONAL RISK MANAGEMENT METHODS}

\section{A. Three traditional risk management methods}

There are three traditional risk management methods: insurance, asset \& liability management and portfolio investment. These three ways are risk measure to eliminate market risk by combining assets and liabilities of the company.
1) Insurance company's management and control of capital use risk

a) Management of asset-liability matching: There are two modes of asset-liability management of life insurance companies, one is an asset-oriented assetliability management model, and the other is a liabilityoriented asset-liability management model.

In theory, the debt-oriented management model is better than the asset-oriented management model. Under the former model, the economic benefit goals of life insurance companies are not contradictory to the interests of insurance customers. Most developed capital markets adopt debt-oriented management models.

However, in the current investment environment of our country, the asset-liability management of life insurance companies should neither adopt a purely asset-oriented model nor a purely debt-oriented model. According to the current situation of my country's life insurance industry, the asset-liability management model of life insurance companies should be a combination of asset-oriented and liability-oriented. On the one hand, life insurance companies must strengthen investment management to match relevant debt requirements as much as possible. On the other hand, in the process of product development, in addition to considering the requirements of the market, the company's investment capabilities should also be considered to minimize the possibility of asset-liability mismatch. The purpose of doing so is to obtain profits under the premise of ensuring the safety of operations and to achieve the goal of sustainable development of my country's life insurance industry. Of course, with the gradual maturity of my country's securities market 
and the improvement of financial products, as life insurance companies have strong investment management capabilities, the asset-liability management model of my country's life insurance industry can adopt more debt-oriented management models. .

b) Control of liquidity risk: A considerable part of the assets in the asset pool of insurance companies are fixed-income assets, and fixed-income assets face greater liquidity risks. The most basic means of controlling liquidity risk is asset-liability matching management. Based on the measurement of assetliability liquidity, the corresponding asset allocation plan is formulated according to the liquidity requirements of the liability, so as to maximize the cash inflow of assets and the cash of liabilities. The outflow matches. In addition, another means of avoiding asset liquidity risk is liquidity quota management, that is, limiting the proportion of assets with poor liquidity and controlling asset quotas with different liquidity levels within a certain range.

c) Interest rate risk control: The management of interest rate risk is divided into asset-based management, liability-based management, and assetliability matching management

Asset-based management mainly uses asset reallocation and financial derivatives to hedge interest rate risk. In addition, options with triggers and average interest rate swap options can prevent surrender risks caused by adverse changes in interest rates. The management methods based on the liability side mainly include prudent reserve management, insurance securitization, and reinsurance. Insurance securitization has become one of the main tools for the insurance industry in the United States and other western developed countries to avoid the risk of interest rate fluctuations. Since life insurance companies are more affected by interest rate risk, insurance securitization is mainly used in the life insurance industry.

d) Credit risk control: In the investment portfolio of insurance companies, certain fixed-income products such as corporate bonds, bank deposits and government bond repurchase businesses also face greater credit risks. In a nutshell, the main content of insurance company credit risk management is to manage the credit risks of the above-mentioned counterparties, provide credit rating recommendations, establish a credit rating system, conduct credit ratings, and issue credit analysis reports. On the basis of credit risk measurement, a credit risk limit allocation plan that meets the company's risk return requirements is formulated according to the credit rating results, and risk control is implemented. Therefore, the core content of insurance company credit risk management is the measurement of credit risk.
In short, as an important means of risk management, insurance calculates the probability of risk and bears the risk through the application of law of large numbers. The emergence of insurance makes property and life insurance to develop. But insurance is not very important in financial risk. Because insurance companies are also responsible for moral hazard in the process of operation, so it increases the risk probability of financial management. Therefore, when choosing insurance companies, it is not recommended to choose companies whose loss ratio is lower than the expected standard. In addition, choosing insurance is more complicated. But insurance risk is a problem that every enterprise must face. The risk is uncertain. Generally, the following measures can be taken to insure. First, risk is accidental, not speculative. Second, there are a large number of potential risks, and the risks are unexpected.

2) The asset liability management method: Asset and Liquidity Management (ALM) is a concept commonly used in financial institutions such as banks, funds and insurance companies. Asset liability management can be divided into broad sense and narrow sense. In a broad sense, asset liability management refers to the target combination of liquidity, security and profitability that financial institutions allocate funds according to certain strategies. In a narrow sense, asset liability management mainly refers to the realization of the objectives of financial institutions by strategically changing the allocation of interest sensitive funds in the environment of interest rate fluctuations, or maintaining the positive net value of financial institutions by adjusting the duration of overall assets and liabilities. Asset liability management has the following necessary components.

- Specific evaluation objectives or financial objectives, such as the maximum legal surplus, the minimum risk of multiplier, the maximum return to shareholders, etc.

- Various constraints, such as the state of state simulation, the given distribution in random simulation, etc.: these conditions are expressed in various forms, such as time series model, stochastic difference equation, etc.

- Solution and calculation results: these methods include deterministic analysis, stochastic programming, stochastic control and so on.

And this method needs to readjust the assets and liabilities of company, so it has some shortcomings. It is mainly reflected in the following aspects. Firstly, it will cost a lot of money to adjust the risk fund and the liability structure of assets. Under certain conditions, it is even necessary to create a trading mode which is symmetry to the basic trading. Secondly, the transaction 
cost is high. In order to match the risk of assets and liabilities, it is necessary not only to negotiate, but also to adjust the corresponding business. It will take a lot of time in this aspect, and in some cases, it will not even be able to complete the agreement. Thirdly, there is credit risk. Sometimes, enterprises have to adjust their projects to achieve a certain goal, which is likely to lose some customers. Moreover, when adjusting the business, at least multiple companies are involved. Therefore, it is difficult to adjust, and the scope of this method is very limited. Fourthly, this way requires negotiation, because there are many businesses involved, it takes a long time, so it can't follow the short-term market. When management measures are actually implemented, risks may have occurred. Therefore, the use of asset and liability method will not only consume funds but also have a slow effect.

3) Portfolio investment: In the traditional market, the way of portfolio investment is the most effective. The main evaluation criteria of this method are investment optimization and expected return. But for investors, what they are facing is a multi-objective decision-making problem, which can't get the maximum profit and the minimum risk at the same time. Therefore, investors can get appropriate returns by using this method. Because the risk and return of portfolio investment lie between all kinds of securities investment, it is widely used. And experts also minimize the risk through models and other ways, But it's more complicated to operate in this way, so data acquisition is difficult.

\section{CONCLUSION}

In today's changing market economy structure, it is a problem for investors to consider at any time to avoid and solve risks. At this time, the use of a series of means in financial engineering can greatly reduce or even avoid the emergence of some risks, while ensuring the normal flow and operation of funds. In short, financial engineering plays an indelible role in maintaining the flow of funds.

\section{References}

[1] Fan Wenhui. On the development and application of financial engineering [J]. Caizhi, 2013, 20: 2.

[2] Liu Yujie, On the comparative advantages of financial engineering in financial risk management, Times Finance 2015 (05) 1-2.

[3] Zhou Li, Comparative Advantages of Financial Engineering in Risk Management, Finance and Economy, 2013 (02) 1-2.

[4] $\mathrm{Li} \mathrm{Xu}$, Research on the Application of Financial Engineering in Exchange Rate Risk Management, Hunan Normal University, 2016 (06) 1-2.
[5] Zhou Bo, Zhang Yayun, Chen Yu. Analyze the application of financial engineering in financial risk management $[\mathrm{J}]$. Value Engineering, 2018, (18).

[6] Ji Qinglin. Analyze the application of financial engineering in financial risk management [J]. Business Stories, 2018, (01). 